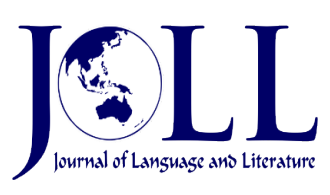

Vol. 21 No. 2, October 2021, pp. $453-463$

DOI: 10.24071/joll.v21i2.3722

Available at https://e-journal.usd.ac.id/index.php/JOLL/index

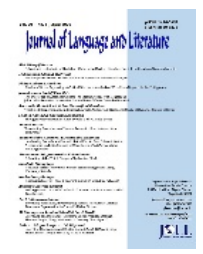

This work is licensed under a Creative Commons Attribution-ShareAlike 4.0 International License.

\title{
Oppression towards Women as Depicted in Marge Piercy's Selected Poems
}

\author{
Diksita Galuh Nirwinastu \\ diksitagaluh@usd.ac.id \\ English Letters Department, Universitas Sanata Dharma
}

\begin{abstract}
This present study would like to examine how women are oppressed by the patriarchal society in the selected poems written by one of the contemporary American female writers, Marge Piercy. Marge Piercy is particularly known as a female writer as well as a feminist activist. She has written numerous works, including novels and poetry books, which explore issues about women. Piercy's poems are mostly known to be simple and vivid. Observing the use of figurative language and the diction in Piercy's selected poems, entitled "A Work of Artifice" and "Barbie Doll", in the light of feminist criticism, this article would like to show how oppression is done towards women and how it results in the silencing, shaping, and subordinating of women. In the poems, the oppression is mostly operated subtly and systematically through various cultural institutions, such as education, family, and media. Women, as a result, are trained to believe in the voice of the patriarchal society and to behave following what the patriarchal society demands. The longpracticed oppression has hindered women to develop to their fullest as human beings. The poems can be read as a medium to voice women's experiences and to criticize the established patriarchal system and its oppression towards women.
\end{abstract}

Article

information

\author{
Received: \\ 12 September \\ 2021 \\ Revised: \\ 5 October \\ 2021 \\ Accepted: \\ 10 October \\ 2021
}

Keywords: oppression; patriarchy; women; Marge Piercy

\section{Introduction}

Scrutinizing patriarchal assumptions and how patriarchy operates in literature is one of the major concerns of feminist literary criticism. Gender stereotypes and how the images of women are represented in literary works often become the focus of a feminist reading. How women are represented in literary works is perceived as one of the ways patriarchy socializes its assumptions to society. The images of women enacted in literature hence are perceived to reflect and contribute to the shaping of women in reality (Leitch, 1988; Barry, 2017). Feminist literary criticism also emphasizes on examining women and their writings. It is pivotal to foreground women's voices in their writings as women in patriarchal traditions are constrained to express their thoughts in public (Leitch, 1988; Mulyani, 2020). Women's experiences are traditionally narrated through 
male lenses and understanding women's experiences from women's perspectives is important in claiming the authority of their images and experiences.

Marge Piercy is one of the female authors who are known as both intellectuals and social activists. She was much involved in the women's suffrage movement in the first wave of feminism and she is now still active in promoting gender equality and women's rights. Known as a prolific writer, Marge Piercy has written 17 poetry books and 13 novels. She has also received numerous awards for her writings. Her works mostly are concerned with culture, women, and class.

The use of simple words, vivid imagery, and strong metaphors have become the characteristics of many of the works of Marge Piercy. In one interview, Piercy says that when a work is expressed "vividly, coherently, and passionately, they pass out the book into life" (Lyons \& Piercy, 2007). In other words, that style will enable a wider range of readers to enjoy and understand the messages carried in Piercy's works.

Numerous research have examined Marge Piercy's works, especially the novels. The first study written by Altman (2003) analyzed three novels written by some secondwave feminists, one of which is Piercy's Small Changes that contains explicit (hetero)sexual revolution by exploring sexuality from the female's perspective. In patriarchal norms, Altman further states that despite the risk of being labeled as trash, those novels provide "a radical terrain of subjectivity for women as they sought individually and collectively to reject a 1950s' medicalized vocabulary" (2003, p. 11). Instead of being considered consciousness-raising, the novels analyzed by Altman are appraised as pornographic, trashy, and unserious because of their vivid portrayals of sexuality. However, Altman argues that depicting sexuality from women's perspectives is crucial since sexuality is mostly written from patriarchal perspective. Women are often not allowed to express their sexuality; their desire and expectation in sexuality. Therefore, Altman argues these novels try to place women as the subject in the realm of sexuality by exploring sexuality from women's perspectives and by naming some sexual terms by themselves.

Another study by Dohal (2019) examines how women are discriminated because of their gender, class, and race in Piercy's utopian novel Woman on The Edge of Time. In that novel, Piercy uses the dystopian future to show the result of discrimination done to women, especially in American society in the twentieth century. Dohal utters that women are categorized and treated based on their sexuality (2019, p. 2). The novel's main character undergoes multiple layers of discrimination because she is a woman, she belongs to a lower-class society, and she is a Mexican American who lives in New York. In the dystopian future seen by the main character, women are portrayed to live in a disastrous world as the result of discrimination towards women in the contemporary world. Piercy wants to warn the readers of this possible catastrophe should the discrimination are kept being done.

Gilarek (2012) studies Piercy's Woman on The Edge of The Time and Russ' The Female Man as two feminist science fiction novels that split the settings of their novels into the present and the future worlds. In Gilarek's research, it is stated that both novels present a subversion and deconstruction of the present binary opposition between the genders. The dystopian world described in the novels is aimed to challenge the patriarchal system and show women's discontent with the patriarchal system.

Although many of the studies conducted on Piercy's works examine the novels, some studies have also been done on Piercy's poems. Padmanugraha (2007) examines one of Piercy's poems entitled "Barbie Doll" and asserts that this poem criticizes the standard of beauty imposed by patriarchy. The doll is used as a symbol of beauty standards in the patriarchy's eyes. In addition, Padmanugraha states that the poem suggests that women should not be valued by their physical appearance only, but also by their personality, life experience, and wisdom. 
Siswanti and Harendika's research (2016) focuses on "Barbie Doll" and "What Are Big Girls Made Of?", two poems by Marge Piercy to explore how women are expected to fulfill society's beauty standards. In a similar tone to Padmanugraha's study, women are valued by their physical qualities only, and the standards used to evaluate women are the patriarchy's. Siswanti and Harendika, furthermore, state that women should not be limited only to their physical qualities (2016, p.140). In another study, Sudha (2017) states that in Piercy's poem entitled "A Work of Artifice", bonsai is used as the extended metaphor to describe women who allow patriarchal society to limit them.

In line with the previous studies conducted on Marge Piercy's works, my article would also examine how women are portrayed in Piercy's selected works, particularly her poems entitled "Barbie Doll" and "A Work of Artifice". However, this present research takes a different focus compared to the previous studies. While the previous research on Piercy's "Barbie Doll" examine the values of women in patriarchal society depicted in the poem, my article would problematize the oppression towards women revealed through the use of figurative language in those two poems. In addition, this article would also take a different stance from the study conducted by Sudha (2017). I perceive that it is not that women allow themselves to be limited by patriarchy, but there is a systematic mechanism of oppression towards women that results in the silence of women in the poem. Thus, the oppression towards women depicted in Marge Piercy's "Barbie Doll" and "A Work of Artifice" becomes the main issue to investigate in this article.

\section{Feminism and Feminist Literary Criticism}

Feminism is both an intellectual and political movement. As an intellectual movement, feminism is discussed and theorized as an academic field, however, feminism also aspires to change the reality (Gamble, 2006; Tong \& Botts, 2018). Feminism as activism is often considered to begin in the 1960 's with the first wave feminism which is concerned with women's rights, including women's access to education and women's right to vote. This wave was also focused on the legal representation of women in society (Sanders, 2006). However, the early stage of feminism had actually started in the sixteenth century numerous writings, such as the one by Mary Wollstonecraft, which promoted the urge to change society's attitude towards women that was rooted in the images created by Judeo-Christian belief. This early feminism tried to voice women in the social and cultural arena and it also led to the rise of the first wave feminism in the 1960's (Hodgson-Wright, 2006). As a political movement, the first wave of feminism succeeded in gaining women's rights to vote and urged wider access for women to access education and enter the workforce.

However, after the "success" of the first wave feminism, there was a need to accommodate the wide range of contexts that have not been accommodated by the first wave feminism. In the 1970's, there was an "explosion of feminist theoretical writings" aimed to theorize the diverse views of feminism, including the diversity of race, class, and sexual orientation (Thornham, 2006). It is expected that by widening the perspectives, feminism would be able to unravel the various ways patriarchy operates in different cultural and social contexts other than the white middle-class women's perspective that dominated the first wave feminism. Hence, it can be seen that feminism is not static; it continuously evolves. Feminism is also not monolithic; in fact, feminism is a "multifaceted movement" (Gamble, 2006).

Feminism believes that, unlike sex which is naturally given, gender is culturally constructed. "One is not born, but rather becomes, a woman" is the notion postulated by Simone de Beauvoir rejecting the essentialist belief that a woman will naturally carry out particular characteristics that become her feminine identity. Beauvoir believes that femininity, the standards assigned to be called a woman, is created by patriarchy; it is a patriarchal myth. Women are perceived as the Other; a male projection of an object that is not male (Thornham, 2006). While men are considered to be logical, women are constructed to be illogical; while men are 
considered to be strong and powerful, women are prescribed to be weak and powerless. Men are assigned the roles to be active in the public sphere while women are assigned the roles to be domestic; to be in the private sphere. Women, in the patriarchal view, possess the traits that men do not possess.

The traits assigned to male and female, however, are not neutral nor equal. Spivak argues that in patriarchy, masculinity is seen as the standard or normative category (Phoca, 2006). Her assertion emphasizes that the category of "woman" is the category that is not standard, deviant, and less than the category of "man", therefore the standard category has the "right" to control and regulate the other. This binary opposition is the root of the oppression experienced by women since the binary structures will always privilege one of the binaries over the other. In other words, patriarchy creates an ideological and cultural system that privileges men (Madsen, 2000). Patriarchy benefits male interests and disadvantages females.

Literature has been an important focus in the struggle of feminism since the early stage of this movement. The increase in women's literacy in the early modern period has encouraged women to be actively involved in literary culture; in reading and writing practices. Literature has then become the means for women to voice and narrate their experiences to the world. Women should voice their views through language and literature that used to be dominated by male to change the world women live in (Rowbotham, 1973). This purpose to resist the patriarchal domination through the creation of art and literature becomes the role of literature as a form of "creative resistance" (Tong \& Botts, 2018).

Feminist literary criticism emerged as a part of the second wave feminism in the 1960s which shows women's resistance against androcentrism in the literature and literary studies. Undermining the patriarchal assumptions through the literary representations of women in literature is perceived as an important step towards women's emancipation (Leitch, 1988; Eagleton, 2007). Feminist literary criticism considers that it is important to demystify the structure underlying the binary opposition used by patriarchy. Therefore, it is crucial for feminism to define and name patriarchy operates and oppresses women through literary representations. Besides examining the literary representations of women, feminist literary criticism also focuses on the works by women to examine how women voice their experiences and stories through literature.

\section{Oppression}

Oppression is often mistaken for prejudice. While prejudice happens at the individual level, oppression happens when the dominant group's prejudice is supported by power (DiAngelo, 2012). The collective prejudice is spread and instilled through a variety of institutions, such as language, family, and economics. This results in the systematic mistreatment of a minoritized group. The word minoritized here is used instead of minority to show there is another party - more powerful and authoritative - that has orchestrated the unequal position. Oppression is systematic in the sense that it is done continuously through a system; it is not random mistreatment. Oppression is also historical, which means that the bad treatments have been practiced for a long time, adapted to cultural changes, and have subtly become parts of daily conduct (Weber, 2010).

DiAngelo (2012) develops a cycle that helps to conceptualize how oppression is done to the oppressed/minoritized group. This cycle would help to understand how oppression is done by patriarchy towards women as the minoritized.

\section{Figure 1. DiAngelo's Cycle of Oppression}

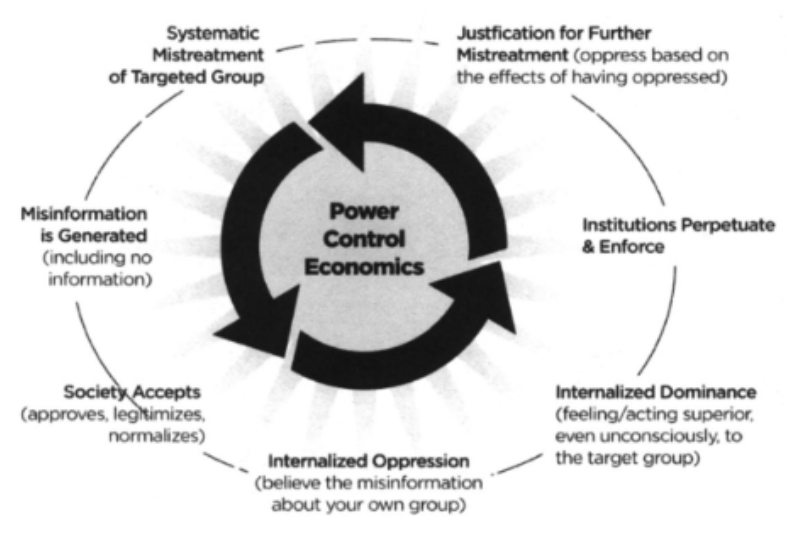


The cycle illustrates how oppression works continuously once the dynamic is set. The misinformation/misrepresentation of a minoritized group is the first step that puts the cycle into motion. The misinformation usually contains the negative representation or images that deny the existence of the minoritized group. Once the misrepresentation is normalized by society, it is circulated and reproduced in that society. Being socially accepted as the truth, the misrepresentation then is utilized to justify the mistreatment. The misrepresentation is not only circulated within the oppressor but also within the oppressed group. They believe that the misrepresentation of them is true; this is called internalized oppression. At this stage, the minoritized group lose their confidence and gain more sense of inferiority.

Other than internalized oppression, DiAngelo also speaks about internalized dominance: the dynamic in which the dominant group believes and internalizes the image that they are more dominant and more superior than the minoritized. This collective misrepresentation is not done individually but enforced by institutions, such as science, media, religious institutions, military, and educational institutions. These institutions are employed to sustain and reinforce the misrepresentation. They might be subtle, but they might also be in the form of force. The last dynamic is the justification for further mistreatment. Oppression is usually transgenerational. The impacts are felt by the next generations and - again - oppression is justified and maintained. Due to the oppression that has been done, it is very possible that the minoritized group "occupies a much lower position" (DiAngelo, 2012). The dominant group would use the minoritized group's lower position to rationalize the oppression and blame the minoritized for their condition.

\section{Explication of the Poems}

This article would examine two poems by Marge Piercy entitled "A Work of Artifice" and "Barbie Doll". This part would explicate each poem.

\section{A Work of Artifice}

"A Work of Artifice" is written by Marge Piercy in 1973 and published in one of her poetry collections in 1999 entitled The Art of Blessing A Day: Poems with A Jewish Theme. The poem has one stanza consisting of 24 lines. Each line is kept short; no single line composes one complete sentence. The lines are all in the form of fragments. Piercy starts the poem with an image of a bonsai tree that is put in a pot by a gardener.

\section{The bonsai tree \\ in the attractive pot \\ could have grown eighty feet tall \\ on the side of a mountain \\ till split by lightning. \\ But a gardener \\ Carefully pruned it. \\ It is nine inches high. \\ (Piercy, 1999, stanza 1, lines 1-8)}

The use of "but" in line 6 indicates the contradiction felt by the speaker. The speaker thinks that the tree actually can grow tall if it grows on the side of a mountain, but in reality, the tree is only nine inches high. As the gardener prunes the bonsai tree, the gardener tells the bonsai tree that it is natural for the tree to be small. Not only does the gardener say that the bonsai tree is naturally small, the gardener also says that having the pot to grow is a piece of luck, a grace for the tree. The saying is expressed utilizing an apostrophe in lines 12-16.
Every day as he whittles back the branches
the gardener croons,
It is your nature
to be small and cozy,
domestic and weak;
how lucky, little tree,
to have a pot to grow in.
(Piercy, 1999, lines 9-16)

In the next lines, the gardener shifts the topic from the bonsai tree to human beings. The gardener says that if living creatures were to be created into bonsai, people must begin shaping them from the early stage of life. The 
last four lines show the ways to make people bonsai. From the shift, it is implied that the bonsai tree is used as a metaphor for human beings.

\author{
With living creatures \\ one must begin very early \\ to dwarf their growth: \\ the bound feet, \\ the crippled brain, \\ the hair in curlers, \\ the hands you \\ love to touch. \\ (Piercy, 1999, lines 17-24)
}

\section{Barbie Doll}

"Barbie Doll" was written by Marge Piercy and published in 1973 in her To Be of Use: Poems by Marge Piercy. The poem consists of 25 lines divided into four stanzas. The poem narrates the life story of a girlchild starting from her birth until her death. Each stanza is dedicated to detail each stage of her life.

This girlchild was born as usual and presented dolls that did pee-pee and miniature GE stoves and irons and wee lipsticks the color of cherry candy. Then in the magic of puberty, a classmate said: You have a great big nose and fat legs.

She was healthy, tested intelligent, possessed strong arms and back, abundant sexual drive and manual dexterity. She went to and fro apologizing. Everyone saw a fat nose on thick legs.

She was advised to play coy, exhorted to come on hearty, exercise, diet, smile and wheedle. Her good nature wore out like a fan belt. So she cut off her nose and her legs and offered them up.

In the casket displayed on satin she lay with the undertaker's cosmetics painted on, a turned-up putty nose, dressed in a pink and white nightie. Doesn't she look pretty? everyone said. Consummation at last. To every woman a happy ending.

(Piercy, 1973)
The poem is very rich of powerful symbol, simile, and irony that help portray the miserable life of the girlchild. The first stanza recounts the early life of the girl comprising her childhood and teenage life. However, starting from her teenage life, her surroundings highlight only her physical appearance - shown by "big nose" and "fat legs" - instead of her health and intelligence. In the second stanza, the girlchild is confused; she apologizes to everyone but, still, everyone only sees her nose and legs. The third stanza tells that the environment keeps telling her what to do and she finally decides to follow the advice, which is cutting her nose and legs. In the fourth stanza, the girlchild is depicted to be dead since she is laying in the casket. It is ironic that while she is dead, people in the funeral compliment her beauty and they say that this is a happy ending for her.

\section{Oppression: Silencing, Shaping, and Subordinating of Women}

This chapter discusses the oppression towards women portrayed in each poem.

\section{A Work of Artifice}

"A Work of Artifice" depicts the oppression towards women through the extensive use of metaphor, apostrophe, and irony. Bonsai tree is used as the main metaphor that represents women under the oppression of patriarchal society in three major aspects: prevented from growing into their maximum potentials, placed in a particular space, and shaped into the design desired by patriarchy.

Bonsai is a Japanese art of growing small trees or dwarfing a tree (Wyman, 1954; Vining, 1971; Hodge, 1972). In the process of shaping a bonsai tree, consistent pruning and watering are needed. A bonsai grower has to carefully prune a bonsai tree to shape and maintain the shape of the tree. Marge Piercy effectively uses this bonsai tree as a perfect metaphor for women under the oppression of patriarchy. 
A bonsai tree is considered to be an art; an enjoyment for the grower. It is shaped into the desired shape of the grower and made into a miniature. Unlike other trees that are grown for their fruits, wood, or any produce of the trees, a bonsai tree is mainly created for an aesthetic purpose; for decoration. There are two methods of taking the tree to be made a bonsai (Wyman, 1954). The first is by taking a tree that is dwarfed by nature, such as growing between the rocks so it lacks nutrition and hence its shape is much smaller than the original. The second way is by taking the seedlings of a woody plant and then dwarfing the plant from the early stage. Both methods require various cultivation techniques from a bonsai grower: pruning, root reduction, potting, and grafting. This long process of creating a bonsai tree is perceived as an art since it requires the patience and skills of a grower. In other words, a bonsai tree is not naturally dwarfed; it is intentionally dwarfed instead.

Similar to the bonsai tree, women also experience the dwarfing process by patriarchy, which is metaphorically represented by the gardener in the poem. Women are prevented from growing into their maximum potentials as the bonsai tree that actually could have grown eighty feet tall if it grows in the natural habitat (lines 1-4). In the poem, the bonsai tree is prevented from growing by the act of pruning that is done by the gardener every day (lines 6-10).

In patriarchy, women are treated as the second sex. They are perceived as less than men; incomplete creatures. Therefore, as the standard category, men have the right to control or shape women. In this poem, the gardener is used as the metaphor for patriarchy, a system that oppresses women. In the beginning, patriarchy is used to refer to a government system in which men become the head of the family, however, in its development, this term is used to refer to a system; a social structure and practice in which men dominate, oppress, and exploit women - not only in the household but also outside the family structure. the domination of men outside the household (Walby, 1989). The belief that women are less than men or inferior to men has been spread continuously by patriarchy, even since the birth of the JudeoChristian belief that blames women (Eve) as the culprit of human (-men)'s fall into evil/sin. This misrepresentation of women as the second sex, as the inferior, as the illogical is spread and has been accepted by society for a long time. Women then are taken as creatures that need to be controlled and shaped by men as the standard category.

This misrepresentation of women - that has been accepted by the truth by patriarchal society - leads to the mistreatment towards women. In the poem, it is said that the bonsai tree is put in "the atrractive pot" (lines 1-2). The pot in this context can be read as the place/space that the patriarchy allows women to have. It is even uttered by the gardener that the bonsai tree is lucky to have the pot (lines 15-16). This pot is, in fact, very limited and oppressing for women. A pot for a bonsai tree functions to limit the growth of the root, which will also function to limit the growth of the upper body of the tree. Similar to the bonsai tree, women are "given" only very limited space to grow as human beings. Women are only allowed to move in the areas/ act in the gender roles permitted by patriarchy (Eisenstein, 1983).

\section{the gardener croons, \\ It is your nature \\ to be small and cozy, \\ domestic and weak; \\ how lucky, little tree, \\ to have a pot to grow in. \\ (Piercy, 1999, lines 11-16)}

Lines 12-16 contain how the gardener croons to the bonsai tree every day as he prunes and whittles back the tree. It is expected that the tree will be small, cozy, domestic, and weak. It can be read as the way how patriarchy circulates the misrepresentation of women to women themselves and society. In patriarchy, women are expected to be dependent and comfortable creatures as illustrated by the use of the words small and cozy. Comfortable here means that women are expected to be the place where men can find pleasure and relief similar to the function of a bonsai tree: decoration and contemplation. The words domestic and weak also imply a similar tone that women should be weak and dependent 
creatures. The word domestic also explains vividly how women are planted to be responsible for domestic issues. While men are assigned the dominant role of aggression, intelligence, and force, women are assigned the role of passivity, ignorance, and docility (Showalter, 1971). From this discussion, it can be seen that women are placed in a pot chosen by patriarchy, that is the role of being dependent and domestic. The use of the word nature implies that women are believed to be essentially (and therefore are supposed to be) inferior to men; women are subordinate to men.

Women, besides being treated as the second sex, are also treated as an object. Like the bonsai tree that is shaped to please and entertain the gardener, women are also shaped to be decoration and pleasure to satisfy the men's desire. It can also be seen from the use of an apostrophe in lines 12-16. A speech in an apostrophe is directed toward another object/character that cannot reply to the speech (Arp \& Johnson, 2006). The apostrophe illustrates how men have the freedom and authority to speak while women are not given any space to talk. Women are depicted to be silenced in the poem by not being given any space to talk or to answer to men. Women are conditioned to fulfill the roles prescribed by patriarchy; they are trained to accept the roles as if women are naturally subordinate to men through various media. This conditioning process creates the internalized oppression in which women subconsciously believe in the false narrative crooned by men to them. It is, therefore, not that women agree with the narrative like what is presented in Sudha's research (2017), but they are conditioned by the patriarchal system. The feelings of women are also not presented in the poem because women are represented by an object; a thing, which is a bonsai tree. The only party that can speak is the gardener - the men.

The last eight lines show the ways patriarchy oppresses women by pruning them; preventing them to grow as human beings.

With living creatures one must begin very early to dwarf their growth: the bound feet, the crippled brain,

the hair in curlers,

the hands you

love to touch.

(Piercy, 1999, lines 18-24)

The oppression towards women is done continuously since the early stage of women's lives. The feet are bound, so women cannot walk or move freely. This might also allude to the foot-binding tradition in China that perceives small feet as a beauty standard. Women's feet are bound, their feet become small so they will be considered beautiful and accepted by society. However, this footbinding also leaves women's feet permanently impaired as the feet will deform and will not be able to function properly. Not only being made unable to walk, women's brains are also crippled. Access to education, leadership, and any other areas that are considered to be public/ belong to men is pivotal in women's development. In traditional gender roles, women are prohibited to be in the public sphere because women are believed as incapable of performing the roles. In many parts of the world, women are still denied access to education and politics. This limitation for women to develop their leadership and intelligence is another form of oppression. Lines 22-24 depict how women are objectified sexually. Women are only seen as body parts that are comfortable to touch.

As the content expresses, the form of the poem also implies how women are dwarfed. Using only fragments in all lines, this poem tries to resemble the shape of a bonsai tree that keeps being pruned and shaped into a small creature. Aimed to be praised as a work of art, Piercy employs a work of artifice instead which summarizes the voice of this poem that women are oppressed and manipulatively deceived by men. The poem expresses how subtle patriarchy oppresses women. Instead of using a loud voice, the gardener croons while pruning the tree. This signifies how patriarchy oppresses women so subtly that women slowly internalize the misrepresentation about themselves and accept it as if it were the reality. 


\section{Barbie Doll}

"Barbie Doll" portrays how the oppression towards women is done particularly through the prescription of beauty standards. This poem mainly employs symbol, simile, and irony to illustrate the suffering experienced by women when being forced to conform to the standards.

Barbie was first produced in 1959 and has become well-known worldwide. Barbie is often idolized as the symbol of feminine beauty. This doll is designed in a sand clock body shape and it has unrealistic body measurements if compared to the real person's body measurement. Barbie comes in various versions and many of which present Barbie wearing various outfits for different jobs. This implies that women can move into the public sphere that is usually dominated by men as long as women fulfill the beauty standards required by men, such as having a slim body and wearing feminine outfits (Rogers, 2009). This ideal beauty standard is then promoted through mass media hence enables the patriarchal values subtly penetrate into daily life. However, "Barbie Doll" views this beauty standard as oppression and rejects the conformity to the standards.

Barbie Doll is taken as the title of this poem and it ironically portrays the suffering of women represented by the girlchild in this piece of poetry. Presented Barbie Doll as the title, the readers will probably expect the poem to talk about the doll. However, the poem reveals that the girlchild does not meet the beauty standards and she is forced to fulfill the standards.

Similar to "A Work of Artifice", "Barbie Doll" expresses that oppression towards women is done since the early stages of a woman's life. In this poem, family becomes the means of oppression by promoting the patriarchal values since the beginning of a woman's life. It is portrayed that the girlchild has been exposed to femininity since her childhood which is shown in lines 2-4. She was given dolls, stoves, irons, and red lipsticks that signify the domestic roles assigned to women in patriarchal society. Women are expected to take care of babies, cook for the family, and be attractive by putting on some cosmetics. The tension starts to appear in lines 5-6 where the girlchild is criticized because of her physical appearance in her teenage. The girlchild is portrayed to be healthy, strong, and intelligent in her teenage, however, those good characteristics do not seem to satisfy the society because the characteristics possessed by the girl are not the ones the society expects a woman to have. Women are assigned the role to be passive, weak, and docile; while the girl possesses the characteristics often assigned to men. Therefore, she is still criticized by the society. In line 10 , she is depicted as "she went to and fro apologizing" (Piercy, 1973) the girlchild starts to internalize the misrepresentation and takes the beauty standards as the truth.

Women are forced to fit the beauty standards prescribed in the patriarchal society. In lines 12-14, the girl was advised to be submissive and to fulfill men's desire as the ultimate goal of her life. None of the advice given to her focuses on her own life and identity as a woman, but focuses on men's desire instead. By utilizing a simile in lines 15-16, Piercy shows how women ironically submit to the standards.

\author{
Her good nature wore out \\ like a fan belt. \\ So she cut off her nose and her legs \\ and offered them up. \\ (Piercy, 1973, lines 15-18)
}

The fan belt is used to represent the girl's original characteristics. Like how important a fan belt is to run a machine, the original characteristics of the girl are the elements that enable the girl to live. However, the girl finally decides to give up and conform to the beauty standards. The words nose and legs in lines 6, 11 , and 17 are used to symbolize the original characteristics and physical appearance of the girl. Unlike Barbie's, the girl's nose is big and the girl's legs are fat; they do not meet the beauty standards prescribed by the patriarchal society.

By conforming to the beauty standards, the girlchild aspires to live and to be accepted by society. Ironically, the girlchild is depicted as dead instead after she conforms to the 
beauty standards. In the last stanza, the girlchild is portrayed as being in a casket; she is surrounded by people confirming that she is beautiful. She does not have her big nose anymore; she has a turned-up nose instead, as suggested by her surroundings. In the casket, she is dressed in pink and white; the colors that are often associated with femininity. It is an irony that the girl is accepted not when she is alive with her original characteristics and physical appearance, but when she is dead after following the prescriptions of patriarchy. This miserable life is called a happy ending for women.

\section{Conclusion}

In patriarchy, women are positioned as inferior and subordinate to men. This view is instilled through various daily practices and cultural institutions, such as education, family, and religion. This collective misrepresentation then results in the oppression of women in society. Marge Piercy's "A Work of Artifice" and "Barbie Doll" reveal how women are shaped, subordinated, and silenced under the patriarchal system. In "A Work of Artifice", Piercy uses bonsai tree to represent how women are dwarfed and treated as an object for satisfying men's desire. "Barbie Doll" expresses how women are forced to conform to the standards created by patriarchy. Both poems criticize the oppressions by saying that the conformity to the patriarchal standards will result in the continuous silencing of women.

\section{References}

Altman, M. (2003). Beyond Trashiness: The Sexual Language of 1970s Feminist Fiction. Journal of International Women's Studies, 4(2), 7-19. Retrieved from

https://vc.bridgew.edu/jiws/vol4/iss $2 / 2$

Arp, T., \& Johnson, G. (2006). Perrine's Literature: Structure, Sound, and Sense (9th ed.). Boston: Thomson Wadsworth.

Barry, P. (2017). Beginning Theory: An Introduction to Literary and Cultural Theory (4th ed.). Manchester: Manchester University Press.

DiAngelo, R. (2012). What Does It Mean To Be White: Developing White Racial Supremacy. Counterpoints, 398, 65-77. Retrieved from https://www.jstor.org/stable/429814 85

Dohal, H. G. (2019). Utopia: Marge Piercy as Social Critic in Woman on the Edge of Time. English Language and Literature Studies, 9(3), 1-7. doi:https://doi.org/10.5539/ells.v9n3 $\mathrm{p} 1$

Eagleton, M. (2007). Literary representations of women. In G. Plain, \& S. Sellers (Eds.), A History of Feminist Literary Criticism (pp. 105-119). New York: Cambridge University Press.

Eisenstein, H. (1983). Contemporary Feminist Thought. Boston: G.K. Hall\&Co.

Gamble, S. (2006). The Routledge Companion to Feminism and Postfeminism. New York: Routledge.

Gilarek, A. (2012). Marginalization of "the Other": Gender Discrimination in Dystopian Visions by Feminist Science Fiction Authors. Text Matters, 2(2), 221-238. doi:https://doi.org/10.2478/v10231012-0066-3

Hodge, W. (1972, September). Japanese Bonsai and Bonsai Shows. Arnoldia, 32(5), 241-248. Retrieved from https://www.jstor.org/stable/429539 02

Hodgson-Wright, S. (2006). Early Feminism. In S. Gamble, The Routledge Companion to Feminism and Postfeminism (pp. 3-14). New York: Routledge.

Krzesni, D. (2015). Oppression. Counterpoints, 503, 19-30. Retrieved from https://www.jstor.org/stable/451365 18

Leitch, V. B. (1988). American Literary Criticism from the Thirties to the Eighties. New York: Columbia University Press.

Lynn, D. (2014). Socialist Feminism and Tripple Oppression: Claudia Jones and 
African American Women in American Communism. Journal for the Study of Radicalism, 1-20. Retrieved from https://www.jstor.org/stable/10.143 21/jstudradi.8.2.0001

Lyons, B., \& Piercy, M. (2007). An Interview with Marge Piercy. Contemporary Literature, 48(3), 327-344. doi:https://doi.org/10.1353/cli.2007. 0040

Madsen, D. (2000). Feminist Theory and Literary Practice. London: Pluto Press.

Mulyani, S. (2020). Revisiting Race, Class, and Gender in Literature and Language. $(\mathrm{H}$. Wijanarka, A. Isti'anah, \& D. G. Nirwinastu, Eds.) Yogyakarta: Fakultas Sastra Universitas Sanata Dharma.

Padmanugraha, A. S. (2007). Woman's Values in Society as Reflected in Marge Piercy's "Barbie Doll". DIKSI, 14(1), 4856.

doi:https://doi.org/10.21831/diksi.v1 $4 \mathrm{i} 1.6547$

Phoca, S. (2006). Feminism and Gender. In S. Gamble, The Routledge Companion to Feminism and Postfeminism (pp. 4753). New York: Routledge.

Piercy, M. (1973). To Be of Use: Poems by Marge Piercy. New York: Doubleday.

Piercy, M. (1999). The Art of Blessing A Day: Poems with A Jewish Theme. New York: Alfred A. Knopf.

Plain, G. (2006). Introduction to Part I. In G. Plain, \& S. Sellers (Eds.), A History of Feminist Literary Criticism (pp. 6-10). New York: Cambridge University Press.

Plain, G., \& Sellers, S. (2006). Introduction to Part II. In G. Plain, \& S. Sellers (Eds.), The Routledge Companion to Feminism and Postfeminism (pp. 102-106). New York: Routledge.

Rogers, M. (2009). Barbie Culture: Ikon Budaya Konsumerisme. Yogyakarta: Relief.

Rowbotham, S. (1973). Woman's Consciousness, Man's World. New York: Penguin Books.

Sanders, V. (2006). First Wave Feminism. In S. Gamble, The Routledge Companion to Feminism and Postfeminism (pp. 1524). New York: Routledge.

Showalter, E. (1971). Women's Liberation and Literature. New York: Harcourt Brace Jovanovich, Inc.
Siswanti, A., \& Harendika, M. S. (2016). Woman The Pretty Sex: An Analysis on Marge Piercy's "Barbie Doll" and "What Are Big Girls Made Of?". Jurnal Ilmiah Edukasi dan Sosial, 7(2), 135-141. Retrieved from http://www.jiesjournal.com/index.ph p/jies/article/view/67

Sudha, T. B. (2017). Marge Piercy's "A Work of Artifice": An Extended Metaphor. Research Journal of English, 2(3), 1822. Retrieved from https://www.rjoe.org.in/Files/vol2iss ue $3 /$ new $/ 2.0 \mathrm{~K} \% 20$ Bhaskara $\% 20$ Sud ha\%2018-22\%20RV.pdf

Thornham, S. (2006). Second Wave Feminism. In S. Gamble, The Routledge Companion to Feminism and Postfeminism (pp. 2535). New York: Routledge.

Tong, R., \& Botts, T. F. (2018). Feminist Thought: A More Comprehensive Introduction. New York: Routledge.

Vining, D. (1971). Bonsai: Nature in Miniature. Arnoldia, 31(5), 274-282. Retrieved from

https://www.jstor.org/stable/429625 87

Walby, S. (1989). Theorizing Patriarchy. Sociology, 23(2), 213-234. Retrieved from https://www.jstor.org/stable/428539 21

Weber, L. (2010). A Conceptual Framework for Understanding Race, Class, Gender, and Sexuality (Vol. 22). New York: Oxford University Press. doi:https://doi.org/10.2307/3211388

Wyman, D. (1954). Japanese Dwarfed Tree. Arnoldia, 14(1), 1-7. Retrieved from https://www.jstor.org/stable/429536 05 